\title{
ARE ALL CROWDS EQUALLY WISE? A COMPARISON OF POLITICAL ELECTION FORECASTS BY EXPERTS AND THE PUBLIC
}

\author{
Lennart Sjöberg $^{1}$
}

\begin{abstract}
Four groups made forecasts of the outcome of the Swedish Parliamentary election in the fall of 2006. They consisted of members of the public, political scientists, journalists writing about domestic politics in Swedish daily newspapers, and journalists who were editing sections of readers' letters in daily newspapers. They estimated, using a 12-step category scale, which percentage of the votes that they believed 7 parties would get in the election. Data were then obtained on the outcome of the election, and on the two opinions polls closest in time to it. When median forecast were compared across groups, it was found that the group from the public was most successful in forecasting the outcome of the election. This was in spite of the fact that the median error made by individual members of that group was about 50 percent larger than the median error made by members of other groups. The two polls were less efficient than the group from the public and overestimated the span between the incumbent government and the opposition by a factor of 2 . The members of the public and journalists showed some wishful thinking in their forecasts. There were large and consistent individual differences in forecasting ability. Men performed better than women, as did those who expressed more interest and knowledge in politics.
\end{abstract}

Key words: election forecast, experts, opinion polls

\footnotetext{
${ }^{1}$. I am indebted to Mona Nettelman for discussions of the design of the study, and to her and Johnny Drottz for locating some of the experts and for data collection. Valuable comments on the manuscript were given by Patric Andersson, Ingolf Ståhl and Torbjörn Thedéen. The study was supported by grants from Andeca Research AB (01/06) and Psykologisk Metod AB (01/06).
} 
Judgments are prone to bias, as shown by Kahneman and Tversky [1]. However, they studied individual judgments, not aggregated results of judgments made by several judges. Under some circumstances, average errors made by individual judges cancel each other and the average judgement may be quite valid [2]. This is especially the case when the judges are independent and do not have a chance to influence each other, and when all the judges have at least some valid information on which they can base their judgments. The averaging approach is being applied to predictions of different social, political, and economic events, with some success [3-5]. Prediction markets often are surprisingly accurate in predicting a number of different events, from political elections to Nobel Prize winners [6-9]. Surowiecki coined the phrase "The Wisdom of Crowds" to describe the phenomenon [2].

One interesting possibility concerns the prediction of the outcome of political elections [1013]. In comparison to election forecasts based on opinion polls, judgments in betting markets have been found to be superior [14-16]. Historical data on betting in US presidential elections show that the winners were picked with good accuracy [17]. Voters have been found to have a considerable degree of forecasting ability [18], yet they are likely to exhibit some wishful thinking. For example, Babad found very strong signs of wishful thinking in a study of Israeli voters [19].

It is interesting to consider the comparison of experts and non-experts. Experts in politics performed well in a German study [20]. Previous research, however, has thrown doubt on the claims often made by experts to make valid forecasts [21-23]. One example is that of stockbrokers [24] who have been found to be no more efficient, even less efficient, than nonexperts are. Yet, they have typically been found to be confident about the validity of their judgments.

Expertise can be based on different claims [25]. One is that of academic credentials. A person with a Ph. D. in political science, and active in an academic setting, would seem to have reasonable claims to expertise in the area of political forecasting, due to knowledge about relevant theory and empirical research in the field. Another approach is to form a group of experts consisting of journalists who write about political issues in daily newspapers. They follow the development in the political arena, and they are professionally articulate about it. They also make qualified, although subjective, analyses of the political process leading up to the election. A third group to consider is that of journalists who work as editors of op-ed letters sent to daily newspapers. Especially in election times, such letters tend to be political in nature, and the editors read many such letters daily. This broad social input could be a valid basis for making forecasts. The editors probably also make their own subjective analyses, but possibly less sophisticated ones than their colleagues who publish analyses and comments on the election campaign events.

All three groups mentioned have of course access to public opinion polls. The polls make up an important type of information, even if they have often been critically assessed. In the Swedish case, there is the problem of low response rates (usually about 50 - 60 percent) ${ }^{2}$, unwillingness to disclose one's political preferences, and memory error. The latter bias is important because the pollsters attempt to correct for low response rate by asking the respondents about their choice in the previous election [26]. Some people have mistaken memories, or are unwilling to disclose which party they voted for. Some did note vote at all (typically 20 - 15 percent). Other problems have to do with the exact phrasing of the poll

\footnotetext{
${ }^{2}$. People with a high level of education are usually over represented among the respondents.
} 
questions [27]. All these errors make opinion polls uncertain, and it is an open question just how much you can trust them. Empirical results are, despite these possible biases, usually good when compared to the election outcome. Corrections based on memory have improved their forecasting ability ${ }^{3}$, in spite of the memory problems.

Summing-up, the three expert groups discussed above, and the public, can be assumed to have access to the following information:

- Political scientists: Opinion polls, research evidence and experience, a few personal contacts

- Journalists: Opinion polls, qualified and articulate subjective analyses, a medium number of contacts

- Editors: Opinion polls, less qualified subjective analyses, many contacts

- Public: Opinion polls, unqualified subjective analyses, a few personal contacts

In addition, members of all groups of course also have access to their own preferences, for what that information may be worth. People overestimate the similarity between themselves and others, and they overestimate the stability of their own opinions [28]. Yet, they are probably aware of, and influenced by, the personal appeal and charisma (or lack of it) of party leaders. This is a factor, which is coming to be seen to be of crucial importance for political attitudes, comparable to policy [29]. Emotional reactions are good predictors of policy attitudes [30].

Comparisons of experts and the public tend to show that experts vary less than the public [31]. The knowledge base for making judgments is probably more varying and vague when it comes to many members of the public. In addition, information from other people is probably an important basis for making political forecasts. Beliefs are affected by social validation, i.e. partly based on what others communicate $[32 ; 33]$. It is likely that the variability of social contacts is larger in samples from the public than in a group of academic researchers or even journalists.

The purpose of the present study was to test the "Wisdom of the crowds" in predicting the outcome of a political election, comparing three groups of experts and journalists with a group from the public. In addition, data from polls were used for comparison purposes. The following hypotheses were to be tested:

(1). Average judgments made by experts and the public are better at forecasting the outcome of an election than late ${ }^{4}$ opinion polls.

(2). Forecasts made by the members of the public will be more variable than forecasts made by the other three groups.

(3). All groups will show wishful thinking, making more optimistic forecasts for their preferred parties than for other parties.

\footnotetext{
3 . Nicklas Källebring, Temo, personal communication, October 5, 2006

${ }^{4}$. It is assumed that the last opinion polls before an election should be the best predictors in the set of polls. This assumption presumes that there are no biasing factors working against the last polls before the election more than they affect other polls.
} 


\section{The election}

The election investigated here was for the Swedish Parliament on September 17, 2006. It was covered intensively in media and it was strongly contested. The incumbent government, run by the Social Democrats since 1994, was challenged by an alliance of four non-socialist parties and polls showed that the outcome was very uncertain. The Social Democrats had been supported by the Left Party and the Greens, forming a socialist block with them.

When the questionnaires had just been mailed, a major event occurred. It was made public that some members of the Liberal Party had gained illegal access to a database managed by the Social Democrats, containing secret election planning material. It was widely expected that this event would hurt the Liberal Party in the election ${ }^{5}$. It will be referred in the following as the "Spy affair".

Many opinion polls were published during the month before the election, giving varying results. Most of them predicted, however, the non-socialist opposition would win with a small margin. See Table 1.

Table 1 here

The table shows that the 22 polls varied strongly. Five predicted a socialist victory, 17 a victory for the non-socialist alliance. The span between the two blocks was computed for each poll. See Fig. 1 for the distribution of spans.

Figure 1 here

The range in estimated share of the votes was large, as shown in Table 1 and Fig. 1. Anyone trying to form an opinion about the coming election result was likely to be confused by the variation in results from the polls, if he or she read about them all. In case reports about just one or a few polls were read, the result may have been less confusing but of course it could have been misleading, depending on which poll was studied.

The election results were in some ways unique. A non-socialist majority was achieved, for only the fourth time since 1932. The Social Democrats got their worst result since 1921; the Conservatives their best since 1928. All seven parties represented in Parliament since 2002 were again represented, and no new party succeeded to achieve 4 percent or more of the vote, which was required for representation in the Parliament. The turnout was 82 percent, a normal figure in Swedish Parliament elections.

\section{Method}

The four groups were located in the following ways:

- Public: A group of 150 people who had participated in a previous survey study [34] and had been part of a strictly random sample of the population. They had responded

\footnotetext{
${ }^{5}$ Decline of the Liberal party in opinion polls had started, however, already before these events.
} 
to that survey and then marked that they would like to take part in future survey studies. Although many did so, they of course diverged from the population at large. In previous research, we have found that a group like this gives responses similar to those from a strictly random sample with a response rate about 50-60 percent [35].

- Political scientists: All faculty members with a Ph.D. degree in political science listed on the home pages of the universities of Lund, Göteborg, Stockholm, Uppsala, and Umeå, 218 persons.

- Journalists: Names of journalists writing about domestic politics were obtained from recent issues of a large number of Swedish daily newspapers, 79 persons.

- Editors of sections on readers' letters: Names were obtained from daily newspapers, 30 persons.

A brief questionnaire was mailed to the respondents two weeks before the election. No reminders were sent. The members of the sample from the public were given a lottery ticket worth SEK 25. No incentives were used for the other groups.

An English translation of the questionnaire can be found in Appendix $1^{6}$. Judgments were to be made of the 7 parties then represented in the Swedish Parliament for the share of votes they could expect to gain. The format for making these judgments used a 12-step category scale, with each category specified as a range of percentages. The reason for using this format was to avoid the otherwise likely clustering of percentage ratings in a few modal values.

The respondents also answered questions about which party they preferred, how certain they were about their judgments, interest in politics, knowledge about politics, and demographics (gender, age, and education). The number of returned questionnaires, and response rates, in each group are given in Table 2.

Table 2 here

The response rates varied and were high in the group from the public, lower in the groups of experts. For the latter groups, response rates were normal for a first mailing. (No reminders were sent). The reason for the high response rate of the group from the public was probably that they had previously stated that they were willing to take part in a new survey study, and that they were given a reward for doing so.

The forecasts made in the four groups were to be compared with election results and two polls: a poll carried out by Temo and an exit poll. The Temo poll was conducted September 13-16 and it involved telephone interviews with 1689 persons. The response rate was 51 percent ${ }^{7}$. The exit poll was conducted with "about 10000 voters", the response rate was "estimated" to have been $70-75$ percent $^{8}$.

\section{Results}

Demographics and questions about party preference, interest, and confidence

The distributions of the respondents' gender, age, and education are given in Table 3.

\footnotetext{
${ }^{6}$ All groups made ratings on the same scales. The questionnaires differed slightly since they explained how the group, to which the respondent belonged, had been defined.

${ }^{7}$ Nicklas Källebring, personal communication, October 5, 2006.

8 Sören Holmberg, personal communication, October 3, 2006.
} 
Table 3 here

It can be seen that the group from the public varied more in demographics than the other three groups and that it had, on the average, a lower education. Its education was still higher than that of the Swedish population. The three groups of experts were dominated by male respondents while the sample from the public was evenly divided between men and women. Table 4 gives information about the party preferences of the respondents.

\section{Table 4 here}

The variability in political preference among the groups was statistically significant, $\chi^{2}=35.9$, $\mathrm{df}=21, \mathrm{p}=0.022$. In particular, it is interesting to see the low preference for the conservatives among the experts, who instead preferred other non-socialist parties. Table 5 gives the level of confidence they expressed in their judgments.

Table 5 here

It is noteworthy there was no significant variation among groups in confidence. Even among the political scientists, there was much uncertainty about the forecast they had made.

Table 6 gives data on rated interest and knowledge about politics. The differences among the groups with regard to self-rated knowledge about politics were highly significant, $\chi^{2}=96.9$, $\mathrm{df}=12, \mathrm{p}<0.0005$. The data on interest were similar to those on self-rated knowledge, and highly significant, $\chi^{2}=122.7, \mathrm{df}=15, \mathrm{p}<0.0005$.

\section{Table 6 here}

Many members of the public have only a low degree of interest in politics [36], while political scientists and journalists naturally can be expected to be much more interested and to have a higher degree of self-rated knowledge.

\section{Forecasting performance and wishful thinking}

Table 7 shows the average forecasts made by the four groups, poll data, and the election results. The data from the public were skew, with a few deviating values. Both arithmetic means and medians are provided for all groups in the tables, but interpretations will be based on medians.

Table 7 here

The main conclusion from Table 7 is that all groups performed quite well. The mean forecasts computed on the basis of median estimates provided by the four groups have been plotted against election results in Fig. 2.

Figure 2 here

The figure shows a high degree of accuracy of forecasts, with only a slight problem in the case of the Social Democrats (noted as "s" in the figure), which were given a somewhat too high estimate. 
The crucial aspect of the election was the distribution of votes across the two blocks of socialist and non-socialist parties. The election resulted in a span of 2.1 percent in favour of the non-socialist alliance. There were clear differences in forecasting performance among the four groups and the two polls. Fig. 3 shows how close the different groups were to the election span between the two blocks, based on median of forecasts.

Fig. 3 here

The best over-all result was achieved by the public. Journalists and political scientists made relatively large errors. Both polls also made relatively large errors, and overestimated the span between the two blocks by a factor of 2 . Hypothesis (1), which stated that subjective forecasts would outperform polls, is supported by these results.

According to Hypothesis (2), there should be a larger variability of forecasts in the group from the public than in the other groups. The standard deviations of the forecasts are given in Table 8. The table shows the experts varied much less in their forecasts than the members of the public did. The standard deviations varied by a factor of 3 between the public and the other three groups, which were similar in this respect, supporting Hypothesis (2). The interquartile ranges varied by a factor of 2 between the public and the other three groups.

Table 8 here

Hypothesis (3) is a statement about wishful thinking. Wishful thinking was assessed by comparing mean and median judgments for each party under two conditions: when it was the preferred party and when it was not. A positive difference between these two values can be interpreted as the result of wishful thinking. See Table 9 for the results ${ }^{9}$. Wishful thinking was clearly present for the public and journalists. The over-all level of wishful thinking was at a relatively low level, with the exception of the group from the public.

Table 9 here

\section{Individual differences}

Errors were computed for each judgment by forming the absolute difference between the judgments and the election result for each of the 7 parties. The intercorrelations among the 7 error scores, in the group from the public, can be found in Table 10.

Table 10 here

An index measuring forecasting ability was formed by taking the mean of the 7 error scores. Coefficient alpha [37] was 0.84 for this index, showing a high level of consistency ${ }^{10}$. The mean error scores were 4.4, 1.9, 1.9, and 2.0 for the public, political scientists, journalists, and editors, respectively. The corresponding medians of error scores were 3.1, 1.9, 1.7, and 2.0. Individual error scores varied between 1.01 and 23.07.

In the public group, the error score was negatively correlated with interest in politics $(\mathrm{r}=$ $0.20, \mathrm{p}=0.026)$ and self-rated knowledge about politics $(\mathrm{r}=-0.23, \mathrm{p}=0.012)$. However, the

\footnotetext{
${ }^{9}$ Data for editors are not reported because the sample size was too small. In several cases, no or only very few editors had reported a party as their preferred one.

${ }^{10}$. The alpha coefficient was 0.84 also when estimated for the entire data set, including all 4 groups.
} 
correlation with confidence in the judgments was smaller $(\mathrm{r}=-0.13$, n.s.). There were also non-significant correlations with age $(\mathrm{r}=-0.13$, n.s.) and level of education $(\mathrm{r}=-0.07, \mathrm{n} . \mathrm{s}$. $)$. There was a large gender difference, $\mathrm{t}(120)=4.66, \mathrm{p}<0.0005$. Men were better election forecasters than women were. The standardized difference was 0.76 , a large difference according to standard criteria [38].

The error scores were standardized across all four groups, and means and medians were computed. The distribution of standardized error scores in the public group was skew, see Fig. 4. There were a few very deviating values of people who had made very inaccurate judgments.

Figure 4 here

A one-way ANOVA of the standardized scores gave the value of $F(3,213)=12.58$, $\mathrm{p}<0.0005$.

The mean standardized error scores were:

- Public: mean 0.34, median -0.07

- Political scientists: mean -0.49 , median -0.45

- Journalists: mean -0.44 , median -0.50

- Editors: mean -0.41 , median -0.41

The means exaggerate the difference between the public and other groups, but the public diverged clearly from the other groups also when medians were used as a basis for making the comparison.

A final check was done to see to which extent gender alone could account for the group differences in forecasting ability. In this analysis, the groups were still quite different, $\mathrm{F}(3$, $206)=7.52, \mathrm{p}<0005$, and so was the gender * group interaction with an $\mathrm{F}(3,206)=2.45$, $\mathrm{p}=0.023$. Although the interaction accounted for a minor effect, it was interesting, see Fig. 5. The figure shows that men and women differed mainly in the public group.

Figure 5 here

\section{Discussion}

The present results confirm earlier research showing the existence of a "wisdom of crowds" and partly support Hypothesis (1). Median forecasts made by members of the public were quite efficient in predicting the outcome of the election. This was in spite of the fact that no monetary incentive was offered for correct predictions. Research on the importance of incentives and real rather than play money rewards tends to agree with this finding: monetary incentives are not necessary for valid predictions [39].

The data show large variability of forecasts in the public group, much larger than in the other three groups. This finding supports Hypothesis (2). In the group from the public, there were large individual differences in ability to make a correct prognosis. Blaisa and Mathieau reported a similar result in a Canadian study [40]. There was a group of respondents who 
made very incorrect judgments. No such group existed among the experts. It is interesting that forecasting ability was only related to gender, not to education or age.

As a group, the members of the public performed well. Should you trust forecasts made by experts or members of the public? It was found that individual members of the public made considerably more erroneous forecasts than experts. On the other hand, "the wisdom of crowds" was very real in the present case. Average forecasts made by a group of the public were quite efficient; individual errors cancelled out.

People betting on the Swedish election also predicted a victory of the alliance. The Betsson company had the odds 1.75-1 for an alliance victory, while the Social Democrats and their backers had the odds 2.08-1. Ladbrokes had 1.90-1 for the Social Democrats and their backers while the odds on the alliance were $1.80-1^{11}$. As mentioned above, most opinion polls made the same prediction, but there were some notable exceptions. SIFO, a well-known Swedish pollster, reported a small advantage for the socialist block as late as September 15.

Forecasts based on opinion polls are faced with the difficult problem of ensuring representativeness of the samples investigated. SIFO and other pollsters are always keen on reporting the number of interviews they have completed, in the case mentioned here $\mathrm{N}=1581$. The exit poll was based on "about 10000 " respondents. The institutes seem to regard the size of the sample as a decisive indicator of quality, and they almost never mention the much more important dimension of response rate. Response rates are usually only moderate, about 50-60 percent, and it is well known that the people who cannot be reached or refuse to answer are systematically different from those who do respond. Due to methodological problems, polls cannot be expected to give a fully accurate prediction of the outcome of an election, even if there is a perfect relationship between stated intentions and actual behavior.

The approach used in the present paper does not need representativeness, only a wide range of people who contribute valid information in their judgments. The present results show that judgments made by members of the public outperformed polls in forecasting efficiency. It should be noted, however, that the judgments made probably used polls as an important information base. If polls had not been available, it is unlikely that judgments had been as efficient as in the present study. People seem to be able to profit from the information in polls and at the same time to add to it more information, which improves their forecasting ability. Human judgment has often been found to improve on forecasts [41].

The group differences in forecasting ability were not accounted for by the large variation in gender composition, but it was found that females in the public sample diverged from other groups in having especially high average error scores. It is clearly important to control for demographics when experts and the public are compared, as illustrated in work on experts' risk perceptions [42].

Wishful thinking was fairly strong in the group from the public and journalists. These findings agree with previous work on political forecasts $[19 ; 43-45]$. The present findings on wishful thinking support Hypothesis (3).

In the heat of an important political election, forecasts play a major role for all actors. Uncertainty is typically at a high level, and many interpretations of events and trends of the polls are possible. The situation is likely to create wishful thinking [46]. Wishful thinking is,

${ }^{11}$. http://news.monstersandcritics.com/europe/article 1201674.php. (Retrieved October 8, 2006) 
in general, undesirable, but an unrealistic level of optimism may turn into a self-fulfilling prophesy, since optimism contributes to vigorous action and hence to success. Among voters, the party expected to win may attract voters for that very reason, a so-called bandwagon effect, which is more likely than the opposite, the "underdog" effect [47].

It would be interesting to include a group of active politicians in future research on political forecasts of the present kind. Possibly, they would show more wishful thinking, at least that is what they often express in media on the eve of an election (and at other times as well). Few studies have been reported on this issue; one showed the opposite effect [48], but this may be an exception. Granberg and Holmberg [49] found stronger wishful thinking in elite groups than in the public, in a study of attitudes towards nuclear power. Dolan and Holbrook [50] found strong wishful thinking effects in US presidential elections, but the effects were attenuated by political knowledge. This finding agrees with the present results showing the political scientists to be low in wishful thinking.

Judgments are often biased and inefficient, whether made by experts or non-experts. Political experts are usually no exception [51]. The present study tells a different story. The likely reason is that most respondents had access to opinion polls, as well as a wealth of other relevant information. The volume of information is, however, of little use if it cannot be integrated and utilized in an efficient manner, as shown by other prediction studies [22; 23]. The information used by the respondents in the present study was seemingly of sufficient quality and useful, good enough to make their average judgments realistic but no guarantee that individual experts or members of the public made correct predictions.

In a study of a German election, Andersson et al. [20] got only a small difference in forecasting ability between experts and voters. Andersson et al. discussed the difference they observed between experts and voters in terms of information superiority of experts, in particular availability of data from polls. They did not analyze their data for gender effects, although it is likely that most of their experts were male. The level of expertise of their experts was probably lower than that of the political scientists in the present study. Besides, their sample of voters was a convenience sample of students in Mannheim and did not vary much in demographic dimensions such as age and level of education. Hence, their experts and voters were probably more similar than the present groups of experts and voters. Their results are not comparable with the present ones due to differences in research design.

Andersson et al. [20] focused on opinion polls as the main information used to make forecasts. Although this seems reasonable, one must remember that polls are doubted by many and even strongly criticised. In addition, different polls seldom agree more than approximately. The strong variation among polls published in the period of data collection for the present study is illustrated in Table 1 and Fig. 1. It was noted above that the two last polls before and just after the election both erred with a factor of 2 in predicting the gap between the two blocks. This was an error much larger than the error made by the sample from the public. The well-known biases of opinion polls and variation among them from institute to institute and day to day, probably motivate many people concerned with making a forecast to think more independently.

Such independent thinking has its virtues but also its dangers. Göran Persson, the then prime minister who was voted out of office on September 17, 2006, made the headlines in August 2006. He claimed that he knew intuitively and with almost perfect accuracy ("down to a half percent") what the opinion in the country was like, just from strolling a few minutes on a 
street in central Stockholm ${ }^{12}$. At the same time, he dismissed opinion polls, and seemingly believed firmly he would win the election. Maybe it would have been better to listen to the polls, or better still, to listen to the forecasts made by voters, journalists and experts - as groups, not individually. It is hard to beat the wisdom of crowds, and hard not to fall prey to wishful thinking.

${ }^{12}$ The lowest mean error score among the present 217 participants was 1.01 percent. 
Table 1. Means and ranges for percentage of vote for 22 polls published during the data collection period. Percent of the vote.

\begin{tabular}{|l|r|r|r|r|r|r|}
\hline & N & Range & Minimum & Maximum & \multicolumn{1}{|c|}{ Mean } \\
\hline Conservatives & 22 & 5.20 & 23.30 & 28.50 & 25.50 \\
\hline Liberal Party & 22 & 4.10 & 7.20 & 11.30 & 9.02 \\
\hline Center Party & 22 & 2.10 & 5.40 & 7.50 & 6.55 \\
\hline Christian Democrats & 22 & 3.50 & 4.80 & 8.30 & 7.18 \\
\hline Green Party & 22 & 2.40 & 4.10 & 6.50 & 5.61 \\
\hline Social Democrats & 22 & 3.60 & 33.10 & 36.70 & 34.87 \\
\hline Left Party & 22 & 2.60 & 5.10 & 7.70 & 6.51 \\
\hline
\end{tabular}


Table 2. Number of respondents taking part in the study and response rates.

\begin{tabular}{|l|c|c|}
\hline Group & $\begin{array}{c}\text { Number of returned } \\
\text { questionnaires }\end{array}$ & Response rate, percent \\
\hline Political scientists & 53 & 24 \\
\hline Journalists & 32 & 41 \\
\hline Editors & 10 & 33 \\
\hline Public & 123 & 82 \\
\hline
\end{tabular}


Table 3. Demographic data of the respondents, column percent.

\begin{tabular}{|c|c|c|c|c|}
\hline & Public & $\begin{array}{l}\text { Political } \\
\text { scientists }\end{array}$ & Journalists & $\begin{array}{l}\text { Editors of } \\
\text { readers' letters }\end{array}$ \\
\hline \multicolumn{5}{|l|}{ Gender: } \\
\hline Men & 49.6 & 80.0 & 81.3 & 70.0 \\
\hline Women & 50.4 & 20.0 & 18.8 & 30.0 \\
\hline \multicolumn{5}{|l|}{ Age: } \\
\hline $18-24$ & 5.7 & & & \\
\hline $25-34$ & 20.3 & 7.5 & 21.9 & 10.0 \\
\hline $35-44$ & 19.5 & 34.0 & 25.0 & 10.0 \\
\hline $45-54$ & 15.4 & 17.0 & 21.9 & 20.0 \\
\hline $55-64$ & 22.8 & 32.1 & 28.1 & 60.0 \\
\hline $65-74$ & 12.2 & 5.7 & 3.1 & \\
\hline $75+$ & 4.1 & 3.8 & & \\
\hline \multicolumn{5}{|l|}{ Education: } \\
\hline Primary & 13.8 & & 3.1 & \\
\hline Secondary & 48.0 & & 31.3 & 20.0 \\
\hline $\begin{array}{l}\text { College or } \\
\text { graduate school }\end{array}$ & 38.2 & 100.0 & 65.6 & 80.0 \\
\hline
\end{tabular}


Table 4. Party preferences of the respondents, column percent.

\begin{tabular}{|c|c|c|c|c|}
\hline Preferred party & Public & $\begin{array}{l}\text { Political } \\
\text { scientists }\end{array}$ & Journalists & $\begin{array}{c}\text { Editors of } \\
\text { readers' } \\
\text { letters }\end{array}$ \\
\hline Center Party & 9.0 & 14.3 & 19.4 & 30.0 \\
\hline Liberals & 9.0 & 24.5 & 19.4 & 20.0 \\
\hline Christian Democrats & 4.9 & 2.0 & 12.9 & 10.0 \\
\hline Green Party & 9.0 & 14.3 & 6.5 & 0.0 \\
\hline Conservatives & 24.6 & 8.2 & 16.1 & 0.0 \\
\hline Social Democrats & 30.3 & 32.7 & 12.9 & 30.0 \\
\hline Left party & 7.4 & 4.1 & 12.9 & 10.0 \\
\hline Other party & 5.7 & & & \\
\hline Total & 100 & 100 & 100 & 100 \\
\hline
\end{tabular}


Table 5. Level of confidence in judgments made by the respondents, column percent.

\begin{tabular}{|l|r|r|r|r|}
\hline Level of confidence & \multicolumn{1}{|c|}{ Public } & \multicolumn{1}{|c|}{$\begin{array}{c}\text { Political } \\
\text { scientists }\end{array}$} & \multicolumn{1}{|c|}{$\begin{array}{c}\text { Editors of } \\
\text { readers' } \\
\text { letters }\end{array}$} \\
\hline Very confident & 3.4 & 2.0 & 3.2 & 0.0 \\
\hline Rather confident & 35.6 & 39.2 & 48.4 & 50.0 \\
\hline Neither/nor & 41.5 & 27.5 & 32.3 & 40.0 \\
\hline Rather uncertain & 17.8 & 23.5 & 16.1 & 10.0 \\
\hline Very uncertain & 1.7 & 7.8 & 0.0 & 0.0 \\
\hline Total & 100.0 & 100.0 & 100.0 & 100.0 \\
\hline
\end{tabular}


Table 6. Self-rated knowledge about and interest in politics, column percent.

\begin{tabular}{|l|r|r|r|r|}
\hline & Public & $\begin{array}{c}\text { Political } \\
\text { scientists }\end{array}$ & Journalists & $\begin{array}{c}\text { Editors of } \\
\text { readers' } \\
\text { letters }\end{array}$ \\
\hline Knowledge: & & & & \\
\hline Very knowledgeable & 2.5 & 48.1 & 34.4 & 40.0 \\
\hline Rather knowledgeable & 36.1 & 48.1 & 59.4 & 60.0 \\
\hline Some knowledge & 46.7 & 3.8 & 6.3 & 0.0 \\
\hline Very little knowledge & 13.1 & 0.0 & 0.0 & 0.0 \\
\hline No or almost no knowledge & 1.6 & 0.0 & 0.0 & 0.0 \\
\hline Interest in politics: & & & & \\
\hline Very strong interest & 2.4 & 43.4 & 31.3 & 50.0 \\
\hline Strong interest & 9.8 & 45.3 & 46.9 & 20.0 \\
\hline Some interest & 45.5 & 11.3 & 21.9 & 20.0 \\
\hline Slight interest & 31.7 & 0.0 & 0.0 & 10.0 \\
\hline Almost no interest & 8.9 & 0.0 & 0.0 & 0.0 \\
\hline No interest & 1.6 & 0.0 & 0.0 & 0.0 \\
\hline
\end{tabular}


Table 7. Forecasts of election outcome of the four groups, polls and election results.

\begin{tabular}{|c|c|c|c|c|c|c|c|}
\hline & \multicolumn{7}{|c|}{ Party } \\
\hline Group & $\begin{array}{l}\text { Center } \\
\text { Party }\end{array}$ & $\begin{array}{c}\text { Social } \\
\text { Democrats }\end{array}$ & $\begin{array}{l}\text { Conserva- } \\
\text { tives }\end{array}$ & Liberals & $\begin{array}{l}\text { Christian } \\
\text { Democrats }\end{array}$ & $\begin{array}{l}\text { Green } \\
\text { Party }\end{array}$ & Left Party \\
\hline $\begin{array}{l}\text { Public, arithmetic } \\
\text { means }\end{array}$ & 10.3 & 36.0 & 28.6 & 11.5 & 8.0 & 7.4 & 8.3 \\
\hline Public, medians & 8.0 & 38.0 & 28.0 & 8.0 & 8.0 & 5.0 & 6.5 \\
\hline $\begin{array}{l}\text { Political scientists, } \\
\text { arithmetic means }\end{array}$ & 7.0 & 35.6 & 25.8 & 8.1 & 6.9 & 5.5 & 5.6 \\
\hline $\begin{array}{l}\text { Political scientists, } \\
\text { medians }\end{array}$ & 8.0 & 38.0 & 23.0 & 8.0 & 8.0 & 5.0 & 5.0 \\
\hline $\begin{array}{l}\text { Journalists, } \\
\text { arithmetic means }\end{array}$ & 7.1 & 35.7 & 24.6 & 8.2 & 7.1 & 5.2 & 5.5 \\
\hline $\begin{array}{l}\text { Journalists, } \\
\text { medians }\end{array}$ & 8.0 & 38.0 & 23.0 & 8.0 & 6.5 & 5.0 & 5.0 \\
\hline $\begin{array}{l}\text { Editors of readers' } \\
\text { letters, arithmetic } \\
\text { means }\end{array}$ & 7.9 & 35.0 & 26.0 & 8.0 & 8.6 & 5.3 & 5.9 \\
\hline $\begin{array}{l}\text { Editors of readers' } \\
\text { letters, medians }\end{array}$ & 8.0 & 35.5 & 25.5 & 8.0 & 8.0 & 5.0 & 5.0 \\
\hline $\begin{array}{l}\text { Temo poll } \\
\text { September } 16 \text {, } \\
2006\end{array}$ & 7.0 & 33.6 & 28.8 & 7.0 & 8.0 & 4.3 & 6.0 \\
\hline Exit poll & 8.2 & 34.3 & 26.6 & 7.3 & 7.6 & 5.5 & 5.8 \\
\hline Election results & 7.9 & 35.0 & 26.2 & 7.5 & 6.6 & 5.2 & 5.9 \\
\hline
\end{tabular}


Table 8. Standard deviations of forecasts.

\begin{tabular}{|c|c|c|c|c|c|c|c|}
\hline \multirow[b]{2}{*}{ Group } & \multicolumn{7}{|c|}{ Party } \\
\hline & $\begin{array}{l}\text { Center } \\
\text { Party }\end{array}$ & $\begin{array}{l}\text { Social } \\
\text { Demo- } \\
\text { crats }\end{array}$ & $\begin{array}{l}\text { Conserva- } \\
\text { tives }\end{array}$ & Liberals & $\begin{array}{c}\text { Christian } \\
\text { Demo- } \\
\text { crats }\end{array}$ & $\begin{array}{l}\text { Green } \\
\text { Party }\end{array}$ & Left Party \\
\hline Public & 6.84 & 6.87 & 8.12 & 6.75 & 4.88 & 6.52 & 6.24 \\
\hline $\begin{array}{l}\text { Political } \\
\text { scientists }\end{array}$ & 2.55 & 3.05 & 3.47 & 2.73 & 1.85 & 1.15 & 1.18 \\
\hline Journalists & 3.27 & 2.84 & 3.46 & 2.16 & 2.52 & 1.06 & 1.34 \\
\hline $\begin{array}{l}\text { Editors of } \\
\text { readers' } \\
\text { letters }\end{array}$ & 2.06 & 3.50 & 4.83 & 2.74 & 2.26 & .95 & 1.45 \\
\hline
\end{tabular}


Table 9. Wishful thinking in making election forecasts, means and medians.

\begin{tabular}{|l|r|r|r|r|r|r|r|}
\hline & \multicolumn{2}{|c|}{ Public } & \multicolumn{2}{|c|}{ Political scientists } & \multicolumn{2}{|c|}{ Journalists } \\
\hline & Means & Medians & Means & Medians & Means & Medians \\
\hline Wishful thinking about the Center Party & -2.9 & 0.0 & 2.6 & 1.5 & 2.4 & -1.5 \\
\hline $\begin{array}{l}\text { Wishful thinking about the Liberals } \\
\text { Wishful thinking about the Christian }\end{array}$ & 4.4 & 4.5 & 0.8 & 0.0 & -1.0 & 0.0 \\
\hline $\begin{array}{l}\text { Democrats } \\
\text { Wishful thinking about the }\end{array}$ & 5.6 & 2.3 & 1.2 & 0.0 & 3.9 & 7.3 \\
\hline $\begin{array}{l}\text { Conservatives } \\
\text { Wishful thinking about the Green Party }\end{array}$ & 1.4 & 3.0 & -0.2 & 0.0 & 1.4 & 1.5 \\
\hline $\begin{array}{l}\text { Wishful thinking about the Social } \\
\text { Democrats }\end{array}$ & 3.6 & 5.0 & 0.6 & -0.5 & -2.5 & 4.0 & 5.0 \\
\hline \begin{tabular}{l} 
Wishful thinking about the Left party \\
\hline
\end{tabular} & 5.0 & 7.5 & 0.9 & 1.5 & 1.2 & 1.5 \\
\hline Mean wishful thinking & 2.5 & 3.2 & 0.8 & 0.1 & 2.1 & 2.7 \\
\hline
\end{tabular}


Table 10. Intercorrelations among error scores, data from the public sample.

\begin{tabular}{|c|c|c|c|c|c|c|c|}
\hline & $\begin{array}{l}\text { Error, } \\
\text { Center } \\
\text { Party }\end{array}$ & $\begin{array}{l}\text { Error, } \\
\text { Liberals }\end{array}$ & $\begin{array}{l}\text { Error, } \\
\text { Christian } \\
\text { Demo- } \\
\text { crats }\end{array}$ & $\begin{array}{l}\text { Error, } \\
\text { Conser- } \\
\text { vatives }\end{array}$ & $\begin{array}{l}\text { Error, } \\
\text { Green } \\
\text { Party }\end{array}$ & $\begin{array}{l}\text { Error, } \\
\text { Social } \\
\text { Demo- } \\
\text { crats }\end{array}$ & $\begin{array}{l}\text { Error, } \\
\text { Left } \\
\text { Party }\end{array}$ \\
\hline Error, Center Party & 1 & 0.78 & 0.51 & 0.42 & 0.43 & 0.27 & 0.50 \\
\hline Error, Liberals & 0.78 & 1 & 0.49 & 0.47 & 0.38 & 0.30 & 0.47 \\
\hline $\begin{array}{l}\text { Error, Christian } \\
\text { Democrats }\end{array}$ & 0.51 & 0.49 & 1 & 0.31 & 0.55 & 0.10 & 0.32 \\
\hline $\begin{array}{l}\text { Error, } \\
\text { Conservatives }\end{array}$ & 0.42 & 0.47 & 0.31 & 1 & 0.40 & 0.40 & 0.26 \\
\hline Error, Green Party & 0.43 & 0.38 & 0.55 & 0.40 & 1 & 0.07 & 0.36 \\
\hline $\begin{array}{l}\text { Error, Social } \\
\text { Democrats }\end{array}$ & 0.27 & 0.30 & 0.10 & 0.40 & 0.07 & 1 & 0.37 \\
\hline Error, Left Party & 0.50 & 0.47 & 0.32 & 0.26 & 0.36 & 0.37 & 1 \\
\hline
\end{tabular}


Fig. 1

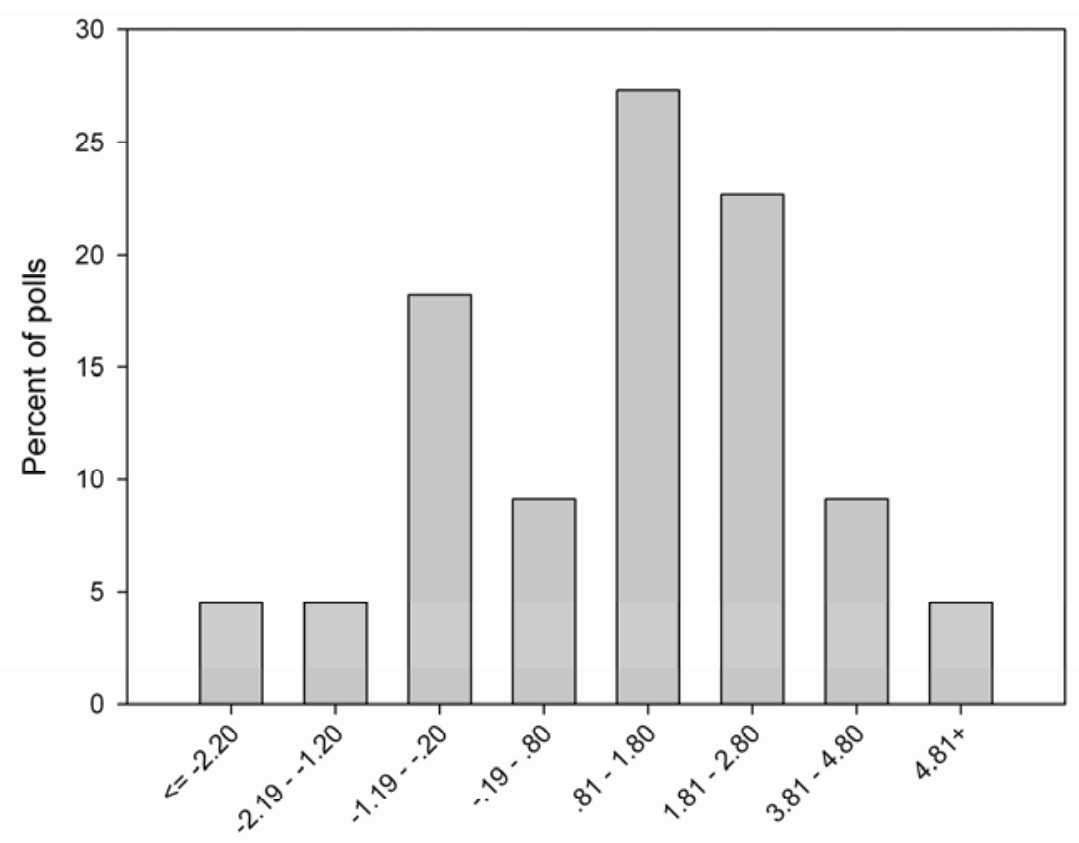

Block difference interval 
Fig. 2

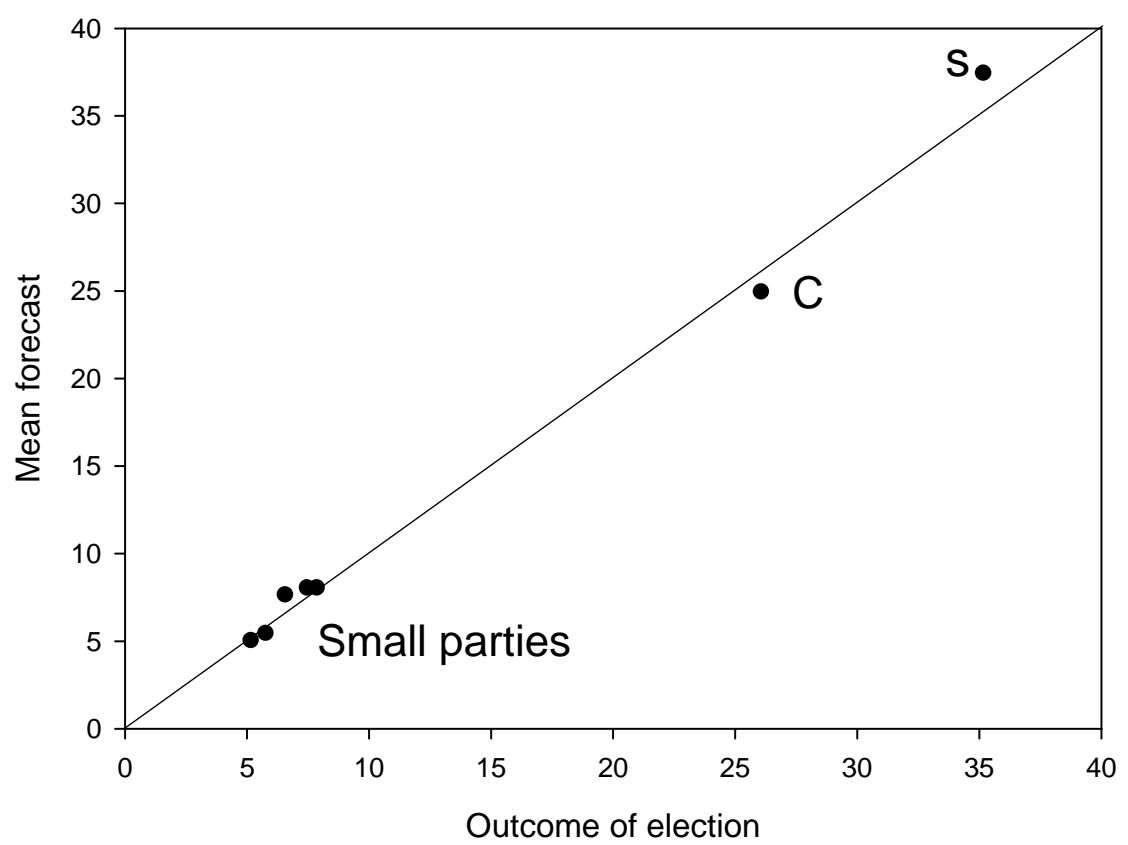


Fig. 3

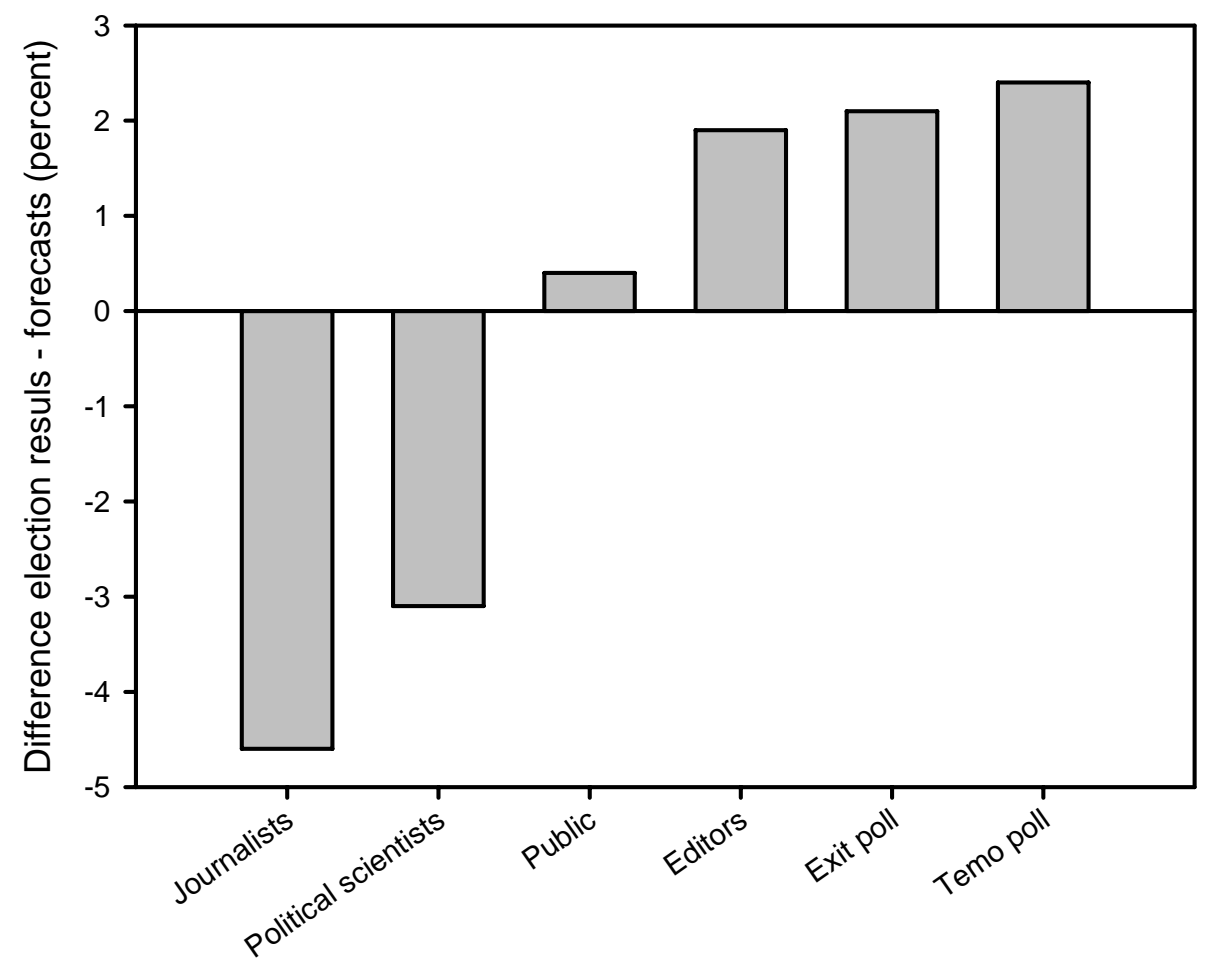


Fig. 4

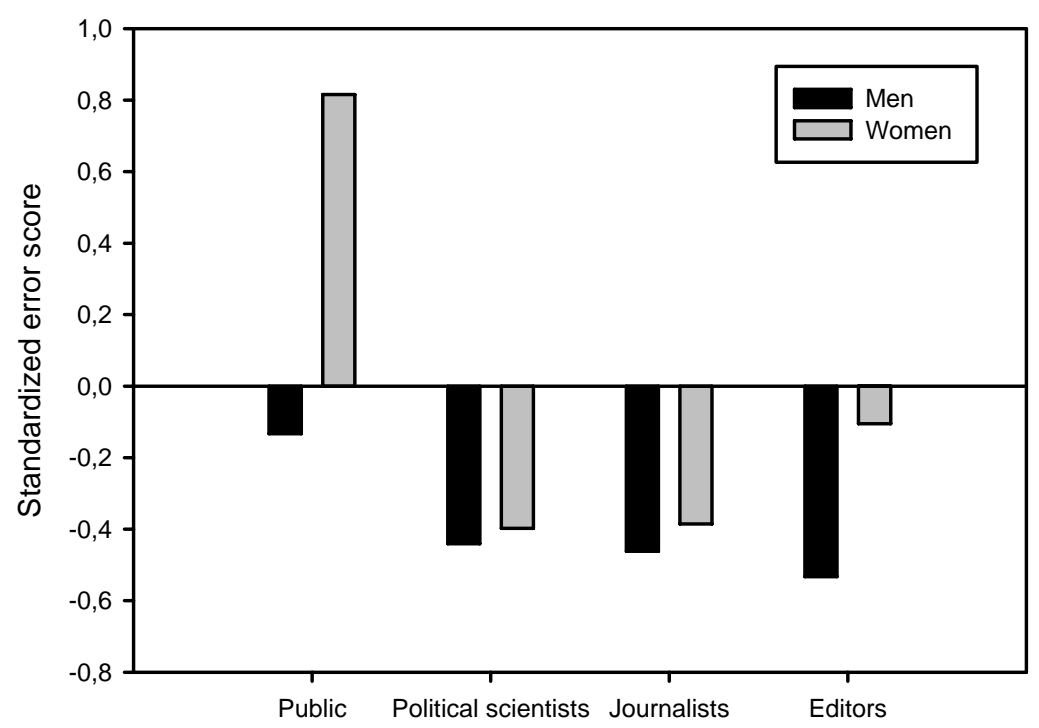


Fig. 5

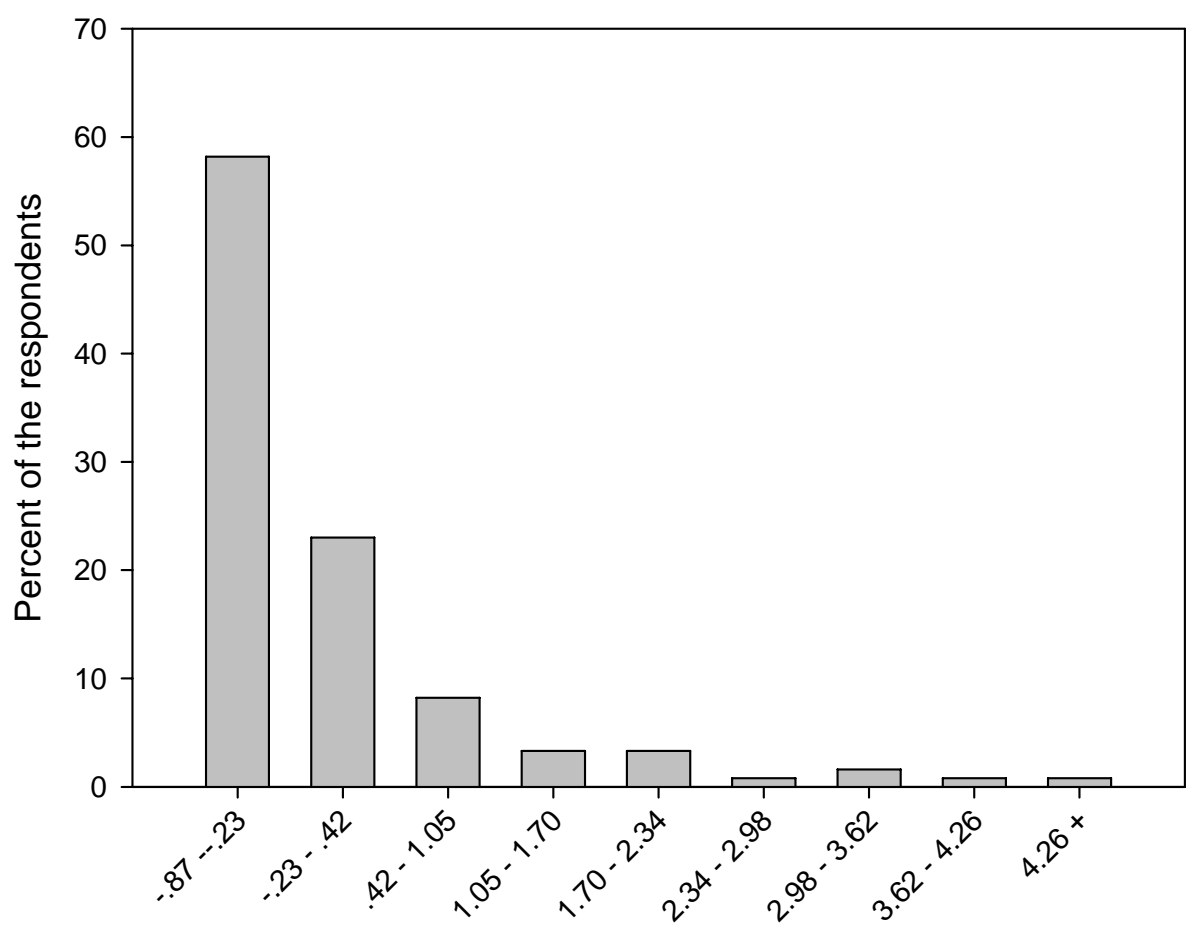

Error score interval 
1. Tversky, A, \& Kahneman, D. Judgment under uncertainty: heuristics and biases. Science 1974; 185: 1124-1131.

2. Surowiecki, J. The Wisdom of Crowds: Why the Many Are Smarter Than the Few and How Collective Wisdom Shapes Business, Economies, Societies and Nations. Doubleday: New York, 2004.

3. Ray, R. Prediction Markets and the Financial "Wisdom of Crowds". Journal of Behavioral Finance 2006; 7: 2-4.

4. Erikson, RS, \& Wlezien, C. (2006). Are Political Markets Superior to Polls as Election Predictors? Paper presented at the Annual Meeting of the American Associationfor Public Opinion Research.

5. Wolfers, J, \& Leigh, A. Three Tools for Forecasting Federal Elections: Lessons from 2001. Australian Journal of Political Science 2002; 37: 223-240.

6. Tziralis, G, \& Tatsiopoulos, I. Prediction markets: an extended literature review The Journal of Prediction Markets 2007; 1: 75-91.

7. Wolfers, J, \& Zitzewitz, E. Prediction markets. Journal of Economic Perspectives 2004; 18: $107-126$.

8. Sunstein, CR. Infotopia. How many minds produce knowledge. Oxford University Press: New York, 2006.

9. Sunstein, CR. Group judgments: Statistical means, deliberation, and information markets. New York University Law Review 2005; 80: 962-1049.

10. Arrow, KJ, Forsythe, R, Gorham, M, Hahn, R, Hanson, R, Ledyard, JO, et al. The promise of prediction markets. Science 2008; 320: 877-878.

11. Tetlock, PE. Expert Political Judgment: How Good Is It? How Can We Know? . Princeton University Press: Princeton, NJ, 2005.

12. Irwin, GA, \& Van Holsteyn, JJ. According to the Polls: The Influence of Opinion Polls on Expectations. Public Opinion Quarterly 2002; 66: 92-104.

13. Lewis-Beck, MS, \& Skalaban, A. Citizen Forecasting: Can Voters See into the Future? British Journal of Political Science 1989; 19: 146-153.

14. Gruca, TS, \& Berg, JE. Public information bias and prediction market accuracy The Journal of Prediction Markets 2007; 1: 219-231.

15. Leigh, A, \& Wolfers, J. Competing approaches to forecasting elections: Economic models, opinion polling and prediction markets. Economic Record 2006; 82: 325-340.

16. Schaffer, LM, \& Schneider, G. The predictive quality of political stock exchanges and polls. Politische Vierteljahresschrift 2005; 46: 674-+.

17. Rhode, PW, \& Strumpf, KS. Historical presidential betting markets. Journal of Economic Perspectives 2004; 18: 127-141.

18. Lewis-Beck, MS, \& Tien, C. Voters as forecasters: a micromodel of election prediction. International Journal of Forecasting 1999; 15: 175-184.

19. Babad, E, \& Yacobos, E. Wish and reality in voters' predictions of election outcomes. Political Psychology 1993; 14: 37-54.

20. Andersson, P, Gschwend, T, Meffert, MF, \& Schmidt, C. (2006). Forecasting the Outcome of a National Election: The Influence of Expertise, Information, and Political Preferences Paper presented at the 2006 annual meeting of the International Communication Association. 
21. Camerer, CF, \& Johnson, EJ. (1991). The Process-Performance Paradox in Expert Judgment: How Can Experts Know So Much But Predict So Badly? In K. A. Ericsson \& J. Smith (Eds.), In Toward a General Theory of Expertise: Prospects and Limits (pp. 195-217). New York: Cambridge University Press.

22. Andersson, P, Edman, J, \& Ekman, M. Predicting the World Cup 2002: Performance and confidence of experts and non-experts. International Journal of Forecasting 2005; 21: $565-576$.

23. Andersson, P. (2004). How well do financial experts perform? A review of empirical research on performance of analysts, day-traders, forecasters, fund managers, investors, and stockbrokers (No. EFI report 2004:9): Stockholm School of Economics.

24. Törngren, B, \& Montgomery, H. Worse than chance? Performance and confidence among professionals and laypeople in the stock market. Journal of Behavioral Finance 2004; 5: $148-153$.

25. Shanteau, J, Weiss, DJ, Thomas, R, \& Pounds, J. Performance-based assessment of expertise: How can you tell if someone is an expert? European Journal of Operations Research 2002; 136: 253-263.

26. Petersson, O, \& Holmberg, S. (2006). Svenska partibarometrar. En dokumentation. Stockholm: SNS.

27. Sjöberg, L. Asking questions about risk and worry: Dilemmas of the pollsters. Journal of Risk Research 2004; 7: 671-674.

28. Lowenthal, D, \& Loewenstein, G. Can voters predict changes in their own attitudes? Political Psychology 2001; 22: 65-87.

29. Benjamin, DJ, \& Shapiro, JM. The Rational Voter, Thinly Sliced:Personal Appeal as an Election Forecaster. NBERA, April 24 2006;

30. Sjöberg, L. Emotions and risk perception. Risk Management: An International Journal 2007; 9: 222-237.

31. Sjöberg, L, \& Drottz-Sjöberg, B-M. Attitudes towards nuclear waste and siting policy: Experts and the public. In A. P. Lattefer (Ed.), Nuclear Waste Research: Siting, Technology and Treatment. New York: Nova Publishers, in press.

32. Cialdini, RB, \& Trost, MR. (1998). Social influence: Social norms, social conformity, and compliance. In D. T. Gilbert, S. T. Fiske \& G. Lindzey (Eds.), The handbook of social psychology. Vol. II (pp. 151-192). Boston: McGraw-Hill.

33. Sjöberg, L, \& Drottz-Sjöberg, B-M. Risk perception by politicians and the public. Energy and Environment 2008; 19: 455-483.

34. Sjöberg, L. Opinion och attityder till förvaring av använt kärnbränsle. (Opinion and attitudes to a repository for spent nuclear fuel) (Research Report No. R-06-97). Stockholm: Svensk Kärnbränslehantering AB, 2006.

35. Sjöberg, L. The perceived risk of terrorism. Risk Management: An International Journal 2005; 7: 43-61.

36. Sjöberg, L. Valet till EU-parlamentet 1995. En socialpsykologisk studie. (The election to the EU Parliament in 1995. A social psychological study). Styrelsen för psykologiskt försvar: Stockholm, 1997.

37. Allen, MJ, \& Yen, WM. Introduction to Measurement Theory. Waveland Press: Long Grove, IL, 2003.

38. Cohen, J, Cohen, P, West, SG, \& Aiken, LS. Applied multiple regression/correlation analysis for the behavioral sciences. Erlbaum: Mahwah, NJ, 2003.

39. Christiansen, JD. Prediction markets: practical experiments in small markets and behaviours observed The Journal of Prediction Markets 2007; 1: 17-41.

40. Blaisa, A, \& Mathieu, T. How good are voters at sorting out the weakest candidate in their constituency? Electoral Studies 2003; 20: 1-7. 
41. Lawrence, M, Goodwin, P, O'Connor, M, \& Onkal, D. Judgmental forecasting: A review of progress over the last 25 years. International Journal of Forecasting 2006; 22: 493-518.

42. Sjöberg, L. The allegedly simple structure of experts' risk perception: An urban legend in risk research. Science Technology \& Human Values 2002; 27: 443-459.

43. Babad, E. Wishful thinking among voters: Motivational and cognitive influences. International Journal of Public Opinion Research 1997; 9: 105-125.

44. Babad, E. Can accurate knowledge reduce wishful thinking in voters' predictions of election outcomes? Journal of Psychology 1995; 129: 285-300.

45. Babad, E, Hills, M, \& Odriscoll, M. Factors influencing wishful thinking and predictions of election outcomes. Basic and Applied Social Psychology 1992; 13: 461-476.

46. Sjöberg, L. The distortion of beliefs in the face of uncertainty. International Journal of Management and Decision Making 2007; 8: 1-29.

47. Mehrabian, A. Effects of poll reports on voter preferences. Journal of Applied Social Psychology 1998; 28: 2119-2130.

48. Lemert, JB. Picking the winners: Politician vs voter predictions of two controversial ballot measures. Public Opinion Quarterly 1986; 50: 208-221.

49. Granberg, D, \& Holmberg, S. A mass-elite comparison of wishful thinking. Social Science Quarterly 2002; 83: 1079-1085.

50. Dolan, KA, \& Holbrook, TM. Knowing versus caring: The role of affect and cognition in political perceptions. Political Psychology 2001; 22: 27-44.

51. Tetlock, PE. Theory-driven reasoning about plausible pasts and probable futures inworld politics: Are we prisoners of our preconceptions? American Journal of Political Science 1999; 43: 335-366. 


\section{Figure Captions}

Figure 1. Distribution of differences between the two blocks in 22 polls.

Figure 2. Mean forecasts, based on all four groups, plotted against election results. $S=$ Social Democrats, $\mathrm{C}=$ Conservatives.

Figure 3. Differences between the block difference according to the election results, and forecasted block difference, based on medians of forecasts.

Figure 4. Mean error scores for men and women and four groups.

Figure 5. Distribution of error scores in the sample from the public. 


\section{APPENDIX}

Questionnaire

\section{WHAT DO YOU THINK WILL BE THE RESULTS OF THE ELECTION?}

We ask you to make a judgment of the results you expect in the upcoming election this fall. We know that it may appear to be difficult, but make a try! Check the square for each party which matches the share of the vote you think it will get in the election. You don't have to check if the sum of the percentages add to 100 .

\begin{tabular}{|l|l|l|l|l|l|l|l|l|l|l|l|l|}
\hline Party & $\begin{array}{l}\text { Less than } \\
4\end{array}$ & $4-6$ & $7-9$ & $10-15$ & $16-20$ & $21-25$ & $26-30$ & $31-35$ & $36-40$ & $41-45$ & $46-50$ & $\begin{array}{l}\text { More } \\
\text { than } 50\end{array}$ \\
\hline $\mathrm{c}$ & & & & & & & & & & & & \\
\hline $\mathrm{fp}$ & & & & & & & & & & & & \\
\hline $\mathrm{kd}$ & & & & & & & & & & & & \\
\hline $\mathrm{m}$ & & & & & & & & & & & & \\
\hline $\mathrm{mp}$ & & & & & & & & & & & & \\
\hline $\mathrm{s}$ & & & & & & & & & & & & \\
\hline $\mathrm{v}$ & & & & & & & & & & & & \\
\hline
\end{tabular}

$\mathrm{c}=$ Center Party, $\mathrm{fp}=$ Liberal Party, $\mathrm{kd}=$ Christian Democrats, $\mathrm{m}=$ Conservatives, $\mathrm{mp}=$ Green Party, $\mathrm{s}=$ Social Democrats, $v=$ Left Party

Which political party do you like best (or dislike least) today when it comes to national politics?

$\square$ Center Party

$\square$ Liberal Party

$\square$ Christian Democrats

$\square$ Green Party

$\square$ Conservatives

$\square$ Social Democrats

$\square$ Left Party

$\square$ Other party than the ones above

How confident are you in your judgment of the upcoming election results?
$\square$ Very certain
$\square$ Rather certain
$\square$ Neither certain nor uncertain
$\square$ Rather uncertain
$\square$ Very uncertain

How interested are you in politics?

$\square$ Very strongly interested

$\square$ Strongly interested 
$\square$ Rather interested

$\square$ Somewhat interested

$\square$ Hardly interested at all

$\square$ Definitely not interested

How knowledgeable are you when it comes to politics?

$\square$ Very knowledgeable

$\square$ Rather knowledgeable

$\square$ Have some knowledge, but not much

$\square$ Have very little knowledge

$\square$ Know nothing or almost nothing about politics

Gender:

$\square$ Man

$\square$ Woman

Age:

$\square$ Younger than 18 years

$\square 18-24$

$\square 25-34$

35-44

$\square 45-54$

$\square 55-64$

$\square 65-74$

$\square 75$ or older

Education (check the "highest" education you have fully completed to a diploma or degree)

$\square$ Elementary school, 9-year compulsory school

$\square$ High school (or other secondary education)

$\square$ College 